bioRxiv preprint doi: https://doi.org/10.1101/143875; this version posted August 1, 2018. The copyright holder for this preprint (which was not certified by peer review) is the author/funder, who has granted bioRxiv a license to display the preprint in perpetuity. It is made available under aCC-BY-NC-ND 4.0 International license.

Masculinity and the mechanisms of human self-domestication-Ben Gleeson

\title{
1 Masculinity and the mechanisms of human self-domestication
}

\section{Ben Thomas Gleeson ${ }^{1}$}

${ }^{1}$ Fenner School of Environment and Society, Linnaeus Way, Australian National University, Acton, ACT, 2601. Email: ben.gleeson@anu.edu.au

This manuscript represents a redrafting of an earlier paper posted at BioRxiv following two rounds of review at Evolution and Human Behaviour. This redrafting will require further changes and review before being resubmitted elsewhere.

The current draft MS contains significant changes from the earlier draft. Valuable feedback provided by previous reviewers suggested the original article was likely to be of interest to readers and, therefore, worthy of eventual publication, but was too wide-ranging, contained sections of excessive speculation, and required further clarification of hypotheses and testable predictions. I acknowledge these concerns and have continued to develop this line of research.

In response to reviewers' comments:

1. The previous MS will now be treated via three separate texts. These will:

i. Explore links between masculinity and the human self-domestication process, including mechanisms of selection on masculine behaviour and morphology (the present draft MS).

ii. Explore possible influences of the self-domestication process upon human beards, i.e. the operation of neural crest cells in the formation of the facial dermis of human males.

iii. Outline links between female preferences for neural crest cell-derived signals of masculinity and vertebrate immunity due to their contributions to the thymus and other immune system components.

2. The present MS, therefore, has had several sections of the earlier draft removed, including the section on beards, which prompted a change of title.

3. A key mechanistic hypothesis of the present MS is that changes to human masculinity, as related to human self-domestication, are likely to involve interaction between testosterone and neural crest cell-derived tissues [a combination of hypotheses provided by Cieri et al. (2014) and Wilkins et al. (2014)]. Existing observational and experimental research is used here to demonstrate the influence of testosterone on growth and development in several key features of domestication syndrome.

4. The counterintuitive observation that males of domesticated non-human species display relatively diminished 'masculinity' but also show relatively elevated testosterone levels, prompts the suggestion that lower androgen receptor density within neural crest cells may drive domesticated reductions in masculinity.

5. These hypothesised interactions between testosterone and neural crest cell-derived tissues require further elaboration and will be a primary avenue for productive future investigation.

6. The next draft of this MS will include a more detailed presentation of previous findings on relevant human evolutionary changes, including: reduced sexual dimorphism; skeletal gracility; brain and tooth size reductions, and altered cranial morphology (brow ridges, jaw size, and the evolution of the human chin). 
1. Introduction

2. NCCs and the domestication process

3. Self-domestication

4. NCCs and male secondary sexual traits

5. Testosterone and NCC-derived masculine features

6. Human self-domestication via selection against masculinity

Abstract

Recent fossil analysis points to 'feminisation' of human cranio-facial morphology as evidence of human self-domestication leading to the emergence of behavioural modernity. Research regarding the biophysical nature of the domestication process more generally, suggests that traits associated with domestication syndrome emerge via hypoplasia of neural crest cell (NCC) derived features. The present article offers an integration of these insights by showing that multiple traits indicative of human masculinity are commonly either directly derived from embryonic NCCs, or are significantly influenced by structures with NCC origins. Based on this observation, a logical expectation is that differential selection on indicators of relative masculinity may moderate processes of human self-domestication. I present a model of human self-domestication based on reductions in mean masculinity and review selective pathways that might achieve this reduction using existing research on selection for or against human masculinity. I suggest female mate choice trade-offs between masculine traits and elevated paternal investment may be a primary driver of human selfdomestication, but also show how self-domestication might relate to other theories of recent 
Masculinity and the mechanisms of human self-domestication-Ben Gleeson

1 human evolution - especially regarding increased human sociability and cooperative capacity. Finally, I discuss potential limitations to the hypothesis and suggest avenues for further empirical investigation of links between masculine traits and the physiology of human self-domestication.

\section{$5 \quad$ Keywords}

6 Masculinity; Neural Crest Cells; Human Self-domestication; Testosterone; Sexual Selection.

\section{Introduction}

8 Recent research concerning domestication syndrome and related human evolutionary change 9 suggests influential roles played by both neural crest cells (NCCs) (Wilkins, Wrangham, \& 10 Tecumseh Fitch, 2014) and prenatal exposure to testosterone (Cieri, Churchill, Franciscus, 11 Tan, \& Hare, 2014). Based on an integration of these insights, and following further review of related evidence, I hypothesise that testosterone provides an elevated regulatory influence on the proliferation of NCC-derived masculine tissues in various taxa, possibly via enhanced densities of androgen receptors within this cell lineage. Multiple male secondary sexual characteristics, previously identified as signals of physiological masculinity, consist of, or are strongly influenced by, structures derived from embryonic neural crest cells (NCCs) (Section 4). It follows, therefore, that since domestication - a physiological process, involving a recognised syndrome of traits - consists of correlated hypoplasia of features composed from NCCs (Wilkins et al., 2014), selection for or against NCC-derived masculine traits should moderate the expression of domestication syndrome within a given lineage. If so, this effect offers substantial physiological insight into previously-described processes of human selfdomestication (Brüne, 2007; Cieri et al., 2014; Fischer, 1914; Franciscus, Maddux, \& Schmidt, 2013; Groves, 1999; Hare, 2017; Leach, 2003; Lorenz, 1940; Wrangham, 2014, 2018).

Given this link to masculinity, female preferences in favour of moderately masculine males due to enhanced pair bonding and paternal investment potential (Kruger, 2006) provide one potential impetus for human self-domestication (Cieri et al., 2014). However, generalisable advantages of increased cooperation may also have promoted this process by dampening male aggression and competition thereby helping to limit intra-group conflict in favour of collaborative intergroup hostilities (Alexander, 1990; Flinn, Geary, \& Ward, 2005; Wrangham \& Glowacki, 2012). In addition, socially-oriented coalitions may have selected 
Masculinity and the mechanisms of human self-domestication-Ben Gleeson

1 against excessively-aggressive masculine individuals using group ostracism and capital punishment (Boehm, 2012, 2014; Pinker, 2011; Wrangham, 2014, 2018).

In effect, the present article proposes and describes a biophysical mechanism consistent with several existing theories of recent human evolution, especially regarding the widely noted emergence of human hyper-sociability and cooperative capacity (Burkart et al., 2014; Burkart, Hrdy, \& Van Schaik, 2009; Hawkes, 2013; Hrdy, 2011; Sterelny, 2011). I begin with a presentation of existing research that links vertebrate NCCs and the domestication process. Following this, I provide evidence for a common association between NCCs and the secondary sexual traits of male vertebrates; including those previously associated with human masculinity. I then explore published observations concerning the interaction of testosterone and NCC-derived tissues and structures and consider this influence as a mechanism in both domestication and varied expressions of masculinity across multiple taxa. Next, I outline some of the implications of these mechanisms with reference to sexual selection and selfdomestication in human evolution. Finally, I conclude by highlighting some apparent limitations of the proposed mechanism and provide suggestions for further research and empirical investigation of this topic.

\section{NCCs and the domestication process}

NCCs are a transient and pluripotent lineage of cells involved in the formation of the vertebrate neural tube. Following the neural tube's formation, these cells disperse along predetermined pathways throughout the developing embryo, providing cellular progenitors for various neural, endocrine, pigment, cardiac, skeletal and dental cells (Gilbert, 2010; B. K. Hall, 2008; J. E. Hall, 2010; Schoenwolf, Bleyl, Brauer, \& Francis-West, 2008). They contribute to the production and patterning of a wide variety of structures and tissues, including: the bones, connective tissues, muscles, and dermis of the craniofacial region; the bones of the middle-ear; the teeth; the hyoid and the larynx; the pigmented melanocytes of vertebrate skin, hair, and feathers; various glands including the thymus, the anterior pituitary, the adrenal medulla and associated autonomic nerve structures; as well as parts of the vertebrate heart (Gilbert, 2010; B. K. Hall, 2008; J. E. Hall, 2010; Matsuoka et al., 2005; McGonnell, McKay, \& Graham, 2001; Schoenwolf et al., 2008; Ueharu et al., 2017). Due to these diverse contributions, NCCs exert a considerable influence on the morphology, physiology and behaviour of all vertebrate taxa, prompting the suggestion they be considered a 'fourth germ layer' in embryonic development (B. K. Hall, 2000). 
Masculinity and the mechanisms of human self-domestication-Ben Gleeson

$1 \quad$ [Figure 1 here] (in development)

2 Figure 1. Embryonic neural crest cell migration pathways and destinations.

3 Domestication syndrome consists of a diverse suite of traits which domesticated animal

4 populations tend to share in common when compared to their wild relatives or ancestors

5 (Hemmer, 1990; Leach, 2003, 2007; Sánchez-Villagra, Geiger, \& Schneider, 2016; L. N.

6 Trut, 1999; Wilkins et al., 2014; Zeder, 2015). The underlying cause of correlated variation in

7 these traits has long been a subject of scientific interest and speculation (Darwin, 1859, 1868;

8 Hemmer, 1990; Jensen, 2006; Zeder, 2015). Recognised symptoms of domestication

9 syndrome include: reduced prognathism; diminished craniofacial cartilage and bone; smaller

10 teeth; smaller crania; diminished size and function of sensory organs; changes in

11 pigmentation; dampened fight or flight responses (i.e. less reactive aggression); elevated

12 docility and sociability towards humans; lessened sexual dimorphism; paedomorphism

13 (generally shifted ontogenic timing); and changed reproductive behaviour and fertility

14 regimes (Hemmer, 1990; Leach, 2003; Sánchez-Villagra et al., 2016; L. N. Trut, 1999;

15 Wilkins et al., 2014; Zeder, 2008, 2015). Based on the observation that most of these traits

16 involve features either directly derived from NCCs, or likely to be affected by NCC-

17 influenced processes, Wilkins et al. (2014) recently proposed that the domestication

18 syndrome emerges in response to heritable alteration in the functioning of embryonic NCCs,

19 and consequent hypoplasia of NCC-derived features-effectively a 'mild neurocristopathy'.

20 Long-running experiments using captive silver foxes (Vulpes vulpes) have demonstrated that breeding selection in favour of increased sociability (or against aggressive reactivity, or 'fight or flight' type responses) induces a range of traits typical of domestication with a given population (Belyaev, 1979; L. Trut et al., 2006; L. Trut, Oskina, \& Kharlamova, 2001; L. N. Trut, Oskina, \& Kharlamova, 2009). This selection is thought to operate by inducing a heritable tendency to a smaller and less responsive adrenal system (Wilkins et al., 2014; but see Kruska, 1988, p. 221 regards reduction in brain limbic structures), a trait long recognized among domesticated populations (Hemmer, 1990). Hypoplasia of the adrenal medulla, along with other components of the autonomic nervous system - also formed from NCC progenitors - is likely to dampen natural levels of behavioural reactivity driven by the Hypothalamic-Pituitary-Adrenal (HPA) axis (Gilbert, 2010; J. E. Hall, 2010; Wilkins et al., 2014). As such, selection for sociability appears to operate via heritable changes in embryonic NCC behaviour and, according to Wilkins et al. (2014), since NCCs provide 
bioRxiv preprint doi: https://doi.org/10.1101/143875; this version posted August 1, 2018. The copyright holder for this preprint (which was not certified by peer review) is the author/funder, who has granted bioRxiv a license to display the preprint in perpetuity. It is made available under aCC-BY-NC-ND 4.0 International license.

Masculinity and the mechanisms of human self-domestication-Ben Gleeson

1 progenitors for multiple other features, this change promotes the broader collection of altered characteristics, as associated with domestication syndrome (Figure 2).

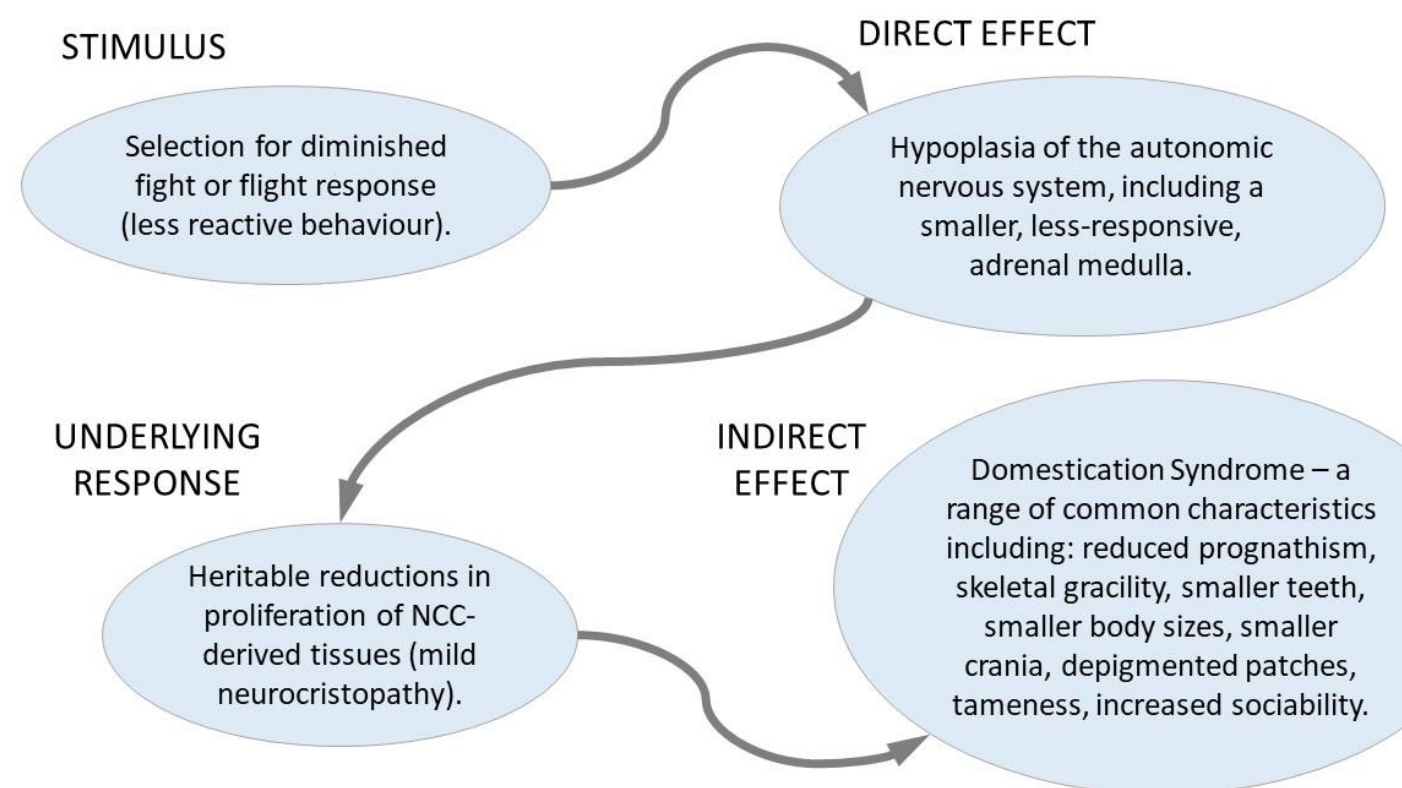

4 Figure 2. Proposed chain of influence in mammalian domestication from Stimulus (selection for less 5 reactive behaviour) to Indirect Effect (Domestication Syndrome) (based on L. Trut et al., 2006, 2001; 6 and Wilkins et al., 2014).

7 Wilkins et al. (2014) argue that this shift in NCC functioning occurs in domesticated animals 8 via either: reduced initial quantities, reduced migration, or reduced in-situ proliferation of 9 NCCs, or their cellular derivatives. They propose dampened migration as the most likely primary mechanism, and expect this effect to result from pleiotropic and epistatic genetic interactions, which could explain noted trait variability between domesticated populations and species (Hemmer, 1990; Sánchez-Villagra et al., 2016; Wilkins et al., 2014). Contra to this emphasis on dispersal, however, documented effects of testosterone on the growth of multiple NCC-derived tissues (discussed further at Section 4) may suggest changes in testosterone-mediated NCC proliferation and growth as a more likely underlying cause.

With regard to pre-historic selection on sociable behaviour, Charles Darwin $(1859,1868)$ originally suggested that a period of 'unconscious selection' of domesticated animals would have preceded any deliberate selection in favour of desirable traits. Following from this, it seems obvious, for reasons of self-preservation, that human domesticators would naturally, and unconsciously, have selected against particularly dangerous or aggressive animals that would have been exceptionally difficult to handle. Since these behaviours are more often 
Masculinity and the mechanisms of human self-domestication-Ben Gleeson

associated with males of many species, we should expect initial selection for less reactively aggressive responses would disproportionately affect the inheritance of associated male traits (Helmer, Goucherin, Monchot, Peters, \& Sana Segui, 2002; Kruska, 1988; Zeder, 2012).

Given demonstrated correlations seen under selection for non-aggressive behaviour (Belyaev, 1979; L. N. Trut, 1999; L. N. Trut et al., 2016), this male biased selection may have been enough to induce domestication syndrome across many species of domesticated animals and would explain why reduced sexual dimorphism is a common feature of domestication. This suggestion - that domestication syndrome initially emerges primarily due to unconscious selection against male aggression — is supported by observations of relatively little selection on females, as evidenced by investigation of mtDNA across multiple domesticated taxa (Marshall, Dobney, Denham, \& Capriles, 2014).

\section{Self-domestication}

Accepting that selection for sociable behaviour originally stimulated the recognised array of correlated traits seen in traditional domesticates, it appears plausible to expect, as some have suggested (Hare, Wobber, \& Wrangham, 2012), that mammalian populations in general will undergo a process of physiological domestication wherever socioecological conditions promote selection for lower reactive aggression and relative sociability. For example, numerous previous authors have documented the contrasting sociosexual behaviour and elevated female social status of bonobos (Pan paniscus) when compared to their close relative, the chimpanzee (P. troglodytes) (Furuichi, 2011; Tokuyama \& Furuichi, 2016; White, 1996; White, Waller, \& Boose, 2013; White \& Wood, 2007). These social conditions are believed to have limited the reproductive benefits of male-male competition, effectively selecting for lower male aggression and allowing for increased sociability in this species (Furuichi, 2011; Hare et al., 2012; Surbeck, Deschner, Schubert, Weltring, \& Hohmann, 2012; Wobber, Hare, Lipson, Wrangham, \& Ellison, 2013). In response to this selection, and in line with experimentally demonstrated changes in captive foxes (L. N. Trut et al., 2006, 2009), wild bonobos appear to have 'self-domesticated' since, when compared to chimpanzees, they show multiple morphological, behavioural and physiological characteristics associated with domestication syndrome (Hare et al., 2012).

Based on observations of similar characteristics in our own species, multiple previous authors have proposed that ancestral humans also underwent a process of self-domestication (Brüne, 2007; Cieri et al., 2014; Fischer, 1914; Franciscus et al., 2013; Groves, 1999; Hare, 2017; 
Masculinity and the mechanisms of human self-domestication-Ben Gleeson

1 Leach, 2003; Lorenz, 1940; Wrangham, 2014, 2018). In relation to earlier Homo sapiens,

2 evidence for this suggestion includes: smaller body sizes and increased skeletal gracility

3 (Frayer, 1980; Frayer \& Wolpoff, 1985; Kappelman, 1996; Ruff, Trinkaus, \& Holliday, 1997;

4 Ruff, 2002; Ryan \& Shaw, 2015); less-masculine facial morphology and reduced

5 prognathism (Groves, 1989; Cieri et al., 2014; Carrier \& Morgan, 2015); less sexual

6 dimorphism (Brace \& Ryan, 1980; Frayer, 1980; Frayer \& Wolpoff, 1985); relative

7 paedomorphism (Gould, 1966, 1977; Alberch, Gould, Oster, \& Wake, 1979; Shea, 1989);

8 smaller cranial capacity (Henneberg, 1988; Henneberg \& Steyn, 1993; Kappelman, 1996; Liu

9 et al., 2014); tooth size reduction (Brace \& Ryan, 1980; Brace, Rosenberg, \& Hunt, 1987;

10 Calcagno \& Gibson, 1988); and increased sociability (Pinker, 2011; Sterelny, 2011, 2012;

11 Cieri et al., 2014; Hare, 2017).

12 Whilst some authors have assumed comparable evolutionary shifts seen in both human and

13 non-human domesticates resulted from shared adaptation to the same modified domestic

14 environment and altered foods (e.g. Brüne, 2007; Leach, 2003), others have proposed

15 behavioural selection in favour of sociability (similar to that applied in the fox experiments)

16 provides a more likely common cause (Cieri et al., 2014; Hare, 2017; Wrangham, 2014,

17 2018). In support of this suggestion, recent expansion in human cultural complexity and technological innovation has been widely proposed to result from enhanced in-group sociability, and an elevated capacity for cooperative interaction (Boehm, 2014; Burkart et al., 2009; Cieri et al., 2014; Flinn et al., 2005; Hare, 2017). Although proposed evolutionary explanations for these changes vary between authors, any increase in sociability would logically imply some form of selection in favour of that sociability. Based on long-standing observational and experimental evidence (Belyaev, 1979; Hemmer, 1990; L. Trut et al., 2006, 2001; L. N. Trut, 1999; L. N. Trut et al., 2009; Wilkins et al., 2014), it seems reasonable to expect such selection to stimulate aspects of domestication syndrome as a natural biophysical response.

\section{NCCs and male secondary sexual traits}

The role of NCCs in the emergence of domestication syndrome is of singular significance to research regarding selection on human masculinity since many previously identified masculine traits involve structures that are either produced, or strongly influenced, by embryonic NCCs and their various cellular derivatives (Table 1). As a principle example, 
Masculinity and the mechanisms of human self-domestication-Ben Gleeson

1 the frontal bone and associated brow ridges, the mandible and maxilla, the nasal bone and

2 cartilage, and the zygomatic arches, as well as influencing the patterning of overlying facial

3 muscles (Cordero et al., 2011; Gilbert, 2010; Knight \& Schilling, 2013). As such, cranial

$4 \quad$ NCCs provide the cellular foundations for all structural indicators of facial masculinity as

5 widely discussed in relation to human sexual selection (e.g. Carré, McCormick, \& Mondloch,

6 2009; Carrier \& Morgan, 2015; Feinberg, DeBruine, Jones, \& Little, 2008; Lefevre, Lewis,

7 Perrett, \& Penke, 2013; Mitteroecker, Windhager, Müller, \& Schaefer, 2015). NCCs also

8 form the dermis of the face and neck, along with associated hair follicles thereby contributing

9 progenitor tissues for human facial hair, especially the male beard (Jinno et al., 2010; Krause

10 et al., 2014; Schoenwolf et al., 2008) which is also a particularly masculine trait and thought

11 to be a focus of sexual selection (Dixson \& Brooks, 2013; Dixson, Rantala, Melo, \& Brooks,

12 2017).

13 Table 1: Several important masculine traits and their relation to NCCs.

\begin{tabular}{|c|c|c|}
\hline Masculine trait & $\begin{array}{c}\text { Previously discussed } \\
\text { by... }\end{array}$ & Influence of NCCs \\
\hline $\begin{array}{l}\text { Facial } \\
\text { dimensions, } \\
\text { including width } \\
\text { to height ratio }\end{array}$ & $\begin{array}{c}\text { Mitteroecker et al. } \\
\text { (2015); Carré et al. } \\
\text { (2009); Lefevre et al. } \\
\text { (2013), Hodges-Simeon } \\
\text { et al. (2016). }\end{array}$ & $\begin{array}{l}\text { NCCs form all of the facial skeleton, including } \\
\text { the frontal bone, mandible, maxilla, zygomatics, } \\
\text { and nasal structures, as well as associated } \\
\text { cartilage and connective tissue (Bhatt, Diaz, \& } \\
\text { Trainor, 2013; Cordero et al., 2011; Santagati \& } \\
\text { Rijli, 2003; Schoenwolf et al., 2008). }\end{array}$ \\
\hline $\begin{array}{l}\text { Large brow } \\
\text { ridges }\end{array}$ & $\begin{array}{l}\text { Dixson (2016); Cieri et } \\
\text { al. (2014). }\end{array}$ & $\begin{array}{l}\text { NCCs provide cellular progenitors of the frontal } \\
\text { bone including the supra-orbital region of the } \\
\text { skull (Mishina \& Snider, 2014; Santagati \& Rijli, } \\
\text { 2003; Schoenwolf et al., 2008). }\end{array}$ \\
\hline $\begin{array}{l}\text { Thick facial } \\
\text { hair }\end{array}$ & $\begin{array}{l}\text { Dixson and Brooks } \\
\text { (2013); Dixson et al. } \\
\text { (2017); Dixson et al. } \\
\text { (2017). }\end{array}$ & $\begin{array}{l}\text { NCCs produce the dermis of the face and neck, } \\
\text { including associated hair follicles (Jinno et al., } \\
\text { 2010; Krause et al., 2014; Schoenwolf et al., } \\
\text { 2008). }\end{array}$ \\
\hline $\begin{array}{l}\text { Lower vocal } \\
\text { pitch }\end{array}$ & $\begin{array}{l}\text { Feinberg et al. (2008); } \\
\text { Puts et al. (2016); Puts } \\
\quad \text { et al. (2006). }\end{array}$ & $\begin{array}{l}\text { NCCs provide progenitor cells of the hyoid, } \\
\text { larynx, and styloid process (Bhatt et al., 2013; } \\
\text { Mishina \& Snider, 2014; Wilkins et al., 2014). }\end{array}$ \\
\hline $\begin{array}{l}\text { Shoulder width, } \\
\text { and shoulder to } \\
\text { hip ratio }\end{array}$ & $\begin{array}{l}\text { Lee et al. (2015) } \\
\text { Windhager et al. (2011). }\end{array}$ & $\begin{array}{l}\text { NCCs provide progenitors for parts of the } \\
\text { shoulder girdle and their connective tissues, and } \\
\text { pattern the development of associated muscles }\end{array}$ \\
\hline
\end{tabular}


Masculinity and the mechanisms of human self-domestication-Ben Gleeson

\begin{tabular}{|c|c|c|}
\hline & & $\begin{array}{l}\text { (Matsuoka et al., 2005; McGonnell et al., 2001; } \\
\text { Noden, 1986; Valasek et al., 2010). }\end{array}$ \\
\hline $\begin{array}{c}\text { Elevated } \\
\text { testosterone } \\
\text { levels }\end{array}$ & $\begin{array}{l}\text { Alvergne et al. (2009); } \\
\text { Burnham et al. (2003). }\end{array}$ & $\begin{array}{l}\text { NCCs contribute to the adrenal and pituitary } \\
\text { glands (Ueharu et al., 2017) influencing the } \\
\text { Hypothalamic-Pituitary-Adrenal and } \\
\text { Hypothalamic-Pituitary-Gonadal axes, both of } \\
\text { which contribute to testosterone production } \\
\text { (Gilbert, 2010; J. E. Hall, 2010). }\end{array}$ \\
\hline
\end{tabular}

2 Further, NCCs form the larynx and hyoid (Gilbert, 2010; Schoenwolf et al., 2008), as well as

3 the styloid process (Bhatt et al., 2013) — an attachment site for muscles that control the tongue and larynx. These contributions suggest altered NCC proliferation, as associated with domestication syndrome, would substantially influence vocal qualities, including voice pitch, another recognized indicator of relative masculinity (Feinberg et al., 2008; Puts et al., 2016; Puts, Jones, \& DeBruine, 2012). NCCs also contribute to the development of the vertebrate shoulder region, influencing its relative size and robusticity by forming sections of the clavicle and scapula bones whilst providing connective sites and tissues, and directing developmental patterning of major neck and shoulder muscles (Ericsson, Knight, \& Johanson, 2013; Matsuoka et al., 2005; McGonnell et al., 2001; Noden, 1986; Valasek et al., 2010). Assuming no associated change in the (non-NCC-derived) pelvis, these contributions suggest varied NCC proliferation should influence both shoulder width and the shoulder-tohip-ratio, which have also been proposed as indicators of relative masculinity (Lee et al., 2015; Windhager et al., 2011).

Many non-human taxa also show conspicuous NCC-derived masculine structures associated with sexually dimorphic physiology and display. In non-human primates, masculinity regularly occurs as sexually dimorphic craniofacial features. Relevant structures include: brow ridges, teeth (especially canines), cheek flanges, and sagittal crests, each of which are derived from embryonic NCC progenitors. Interestingly, male cheek flanges and exaggerated sagittal crests emerge at sexual maturity, or even later in adulthood (Balolia, Soligo, \& Lockwood, 2013; Balolia, Soligo, \& Wood, 2017). This delayed developmental timing demonstrates both stem-cell-like extended potency of the NCC-derived cells involved, as well as interactions with androgen hormones and related social signalling. For instance, male orangutans (Pongo spp.) can subsist for years as adult sub-dominants without cheek flanges, but flanges develop upon achieving relative social dominance (Dunkel et al., 2013; 
Masculinity and the mechanisms of human self-domestication-Ben Gleeson

1 Thompson, Zhou, \& Knott, 2012). As a further example, antlers, which grow annually on males of the Cervidae in response to seasonal testosterone fluctuation, are another NCCderived masculine feature (Davis, Brakora, \& Lee, 2011).

Aside from these pronounced structural traits, varied colouration of hair, skin, and feathers in many vertebrate often relies on melanocytes which are also derived from NCCs (B. K. Hall, 2008; J. E. Hall, 2010). These colours are commonly sexually differentiated, are predominantly darker or more colourful in males of a given taxa, and regularly act as ornaments in intersexual selection (Darwin, 1871; Dubuc, Allen, Maestripieri, \& Higham, 2014; Evans, Goldsmith, \& Norris, 2000; Heck, 1951; Vandenbergh, 1965). As with masculine structures, male colourations are often absent in youth, but emerge at sexual maturity in response to elevated testosterone circulation. In male mandrills (Mandrillus sphinx) adult NCC-derived colouration of the face, rump, and genitalia also fluctuates in association with the testosterone shifts accompanying changed social status (Setchell \& Dixson, 2001). Note, that the structurally-derived blue colouration in mandrills requires an underlying melanocyte layer in the rump which is not present within the NCC-derived blue facial dermis (Prum \& Torres, 2004).

NCCs may also be associated with masculine behaviour in many species. As mentioned, these cells compose multiple components of the peripheral nervous system, including sympathetic and parasympathetic ganglia, and the adrenal medulla (Gilbert, 2010; J. E. Hall, 2010; Schoenwolf et al., 2008; Wilkins et al., 2014). As such, relative proliferation of embryonic NCCs should directly moderate the propensity for autonomic reactivity effected by the Hypothalamic-Pituitary-Adrenal (HPA) axis (Wilkins et al., 2014), especially the socalled 'fight or flight' response. Additionally, NCCs contribute to the development of the anterior pituitary and its various hormone-secreting cells (Ueharu et al., 2017) suggesting they may influence levels of HPA axis reactivity via contributions to both the adrenal and the pituitary glands. Further, NCC contributions to the pituitary suggest potential to moderate other male endocrine functions, including the regulation of testosterone, as well as growth and thyroid hormones.

\section{Testosterone and NCC-derived masculine features}

30 Whilst Wilkins et al. (2014) compellingly highlight associations between NCCs and the 31 majority of traits seen in mammalian domestication syndrome, Cieri et al. (2014) focussed specifically on the potential influence of self-domestication in humans and used ancestral 
Masculinity and the mechanisms of human self-domestication-Ben Gleeson

1 decline in the masculinity of the (NCC-derived) craniofacial region to infer prehistoric reductions in prenatal testosterone exposure. Their observations imply either reduced maternal circulating testosterone, or relatively lessened androgen receptor densities, across the populations studied (Cieri et al., 2014). Here, I employ a logical integration of these studies to suggest that the proliferation of NCCs, or their derived cells and tissues, is often particularly responsive to testosterone.

7 This hypothesis is supported by evidence from multiple previous studies involving NCCderived masculine traits and features. For example, recent research has confirmed a link between levels of prenatal testosterone exposure and hypermasculinised human faces (Whitehouse et al., 2015) as was inferred by Cieri et al. (2014) in relation to human selfdomestication. Circulating testosterone has also been shown to correlate with facial masculinity among both adolescents (Marečková et al., 2011), and in adult men (HodgesSimeon et al., 2016; Lefevre et al., 2013; Penton-Voak \& Chen, 2004). Aside from these comparative studies, experimental work by Verdonck et al. (1999) showed testosterone treatment in boys with unusually delayed puberty led to increased upper and total facial height. In addition, administration of anabolic steroids in young rats has been shown to cause increased length of the craniofacial skeleton, especially the midface, maxilla, and mandible (Barrett \& Harris, 1993). Conversely, neonatal and prepubertal castration in rats causes diminished craniofacial growth, especially with regard to anterior length (Verdonck et al., 1998).

As described in Section 3, numerous masculine signals in wild non-human taxa-including sagittal crests, cheek flanges, antlers, and various colourations - are NCC-derived and conspicuously responsive to fluctuations in circulating testosterone. In humans, the effects of elevated pubertal testosterone are also well established; involving various NCC-derived masculine traits, including: growth and development of the larynx leading to altered vocal pitch; the growth of thick facial hair from the dermis of the face and neck; and increased structural masculinity of the facial region; among other testosterone-mediated changes (Gilbert, 2010; Widmaier, Raff, Strang, \& Vander, 2010).

Interestingly, recently described NCC contributions to the anterior pituitary (Ueharu et al., 2017) suggest a circular relationship between testosterone production and NCC proliferation since it implicates NCCs in the function of the Hypothalamic-Pituitary-Gonadal (HPG) axis, the principal regulatory system for male testosterone production (Gilbert, 2010; J. E. Hall, 
Masculinity and the mechanisms of human self-domestication-Ben Gleeson

1 2010). Wilkins et al. (2014) also hypothesised a connection between altered NCC behaviour, domestication syndrome, and the HPG axis in their discussion of the shifted timing of reproductive physiology among domesticated female foxes. However, these authors do not consider the potential effect of suppressed NCC activity upon the HPG axis of male foxes, nor upon the subsequent production of testosterone.

6 Aside from small quantities produced by the (NCC-derived) adrenal medulla, most male 7 testosterone is produced within the Leydig cells of the testes, a process triggered by the 8 release of luteinizing hormone from the anterior pituitary (Gilbert, 2010; J. E. Hall, 2010).

9 Therefore, the fact that this important gland receives significant input from NCC lineages appears to suggest a functional link between decreased proliferation of NCCs, lower production of pituitary luteinizing hormone as part of the HPG axis, and generally lower levels of testosterone production in less-masculine males. If this description were accurate, we would expect both less-masculinised individuals and domesticated populations in general, to show lower circulating testosterone levels than their more-masculine, or non-domesticated, ancestors and relatives.

However, whilst this relationship appears to have been demonstrated with regard to variation in masculinity among modern humans (Lefevre et al., 2013; Penton-Voak \& Chen, 2004), available research does not support the same relationship in domesticated versus nondomesticated animal comparators. Researchers comparing adolescent guinea pigs with wild cavies (the nearest non-domesticated relative) (Künzl \& Sachser, 1999; Zipser, Schleking, Kaiser, \& Sachser, 2014), and wild mouflon sheep with 10 domesticated breeds and crossbreeds (Lincoln, Lincoln, \& McNeilly, 1990), actually found higher testosterone concentrations in the domesticated forms.

These counterintuitive contrary results may be a logical (though unexplained) aspect of changes to the feedback systems of endocrine regulation under domestication syndrome, or may result from directional human selection in favour of elevated reproductive performance in domesticated male animals (e.g. see Katz, 2007). Either way, it suggests that hypoplasia of NCC-derived masculine features does not result simply from reduced testosterone levels, and supports Cieri et al.'s (2014) alternative inference (in relation to humans) that androgen receptor densities are the point of difference between domesticated and non-domesticated comparators. Following from this proposal, the specific mechanistic hypothesis presented in 
Masculinity and the mechanisms of human self-domestication-Ben Gleeson

1 the current paper is that domesticated hypoplasia of masculine features relies on a lower density of androgen receptors, particularly within NCC-derived cells and tissues.

\section{Human self-domestication via selection against masculinity}

Accepting there has been an evolutionary trend toward human self-domestication and given the proposal that this occurred primarily as selection for sociability which led to mean reductions in NCC-derived masculinity, it remains to consider what evolutionary pressures are likely to have promoted this socialisation process. Recent research explicitly describing human self-domestication has identified three primary mechanisms; these are: (1) general social benefits, whereby improved sociability would provide enhanced survival and Darwinian fitness via cooperative exchange (Cieri et al., 2014; Hare, 2017); (2) group ostracism, where groups naturally ostracise, or exact capital punishment upon, excessively aggressive and dominant individuals (Wrangham, 2014, 2018); and (3) female mating preferences, whereby women would preferentially select for more sociable and lessmasculine male reproductive partners who are more inclined to paternal investment strategies (Cieri et al., 2014).

With regard to the latter proposal, previous research examining women's preferences for men's masculine traits has suggested these vary depending on menstrual cycling and whether long or short-term relationships are sought (DeBruine, Jones, Frederick, et al., 2010; Gangestad \& Thornhill, 2008; Little, Saxton, et al., 2010; Little, Jones, \& Burriss, 2007; Penton-Voak et al., 1999; but see Harris, 2013; and Wood, Kressel, Joshi, \& Louie, 2014). Further, such preferences appear to be enhanced under conditions of high pathogen presence (DeBruine, Jones, Crawford, Welling, \& Little, 2010; Little, DeBruine, \& Jones, 2010) and elevated social inequality (Brooks et al., 2010). These observations conform to expectations that women are adaptively predisposed to making context-dependent mating choices between males with either 'good genes' (and elevated masculinity), or those with a higher propensity for pair-bonding and paternal investment (Kruger, 2006; Little, Connely, Feinberg, Jones, \& Roberts, 2011; Quist et al., 2012; Trivers, 1972).

Boothroyd et al. (2017) recently showed a significant non-linear correlation between facial masculinity and offspring survival in two traditional human groups. In this study, moderately masculine fathers had lower offspring mortality than those with both relatively low and relatively high masculinity (Boothroyd et al., 2017). Combined with existing sexual selection theory (Kruger, 2006; Trivers, 1972), this result appears to indicate the relatively limited 
Masculinity and the mechanisms of human self-domestication-Ben Gleeson

survival of offspring from either theoretical extreme on the continuum between 'low masculinity, but higher inclination to paternal investment', and 'high masculinity, but low paternal investment'. It suggests a centralised optimum of masculinity regards offspring survival, and a degree of stabilizing selection with implications for the adaptiveness of female preferences toward either extreme (Boothroyd et al., 2017).

Though not explicitly addressing human self-domestication, the work of several other authors supports potentially related evolutionary mechanisms more reminiscent of the 'social benefits' (Cieri et al., 2014) and 'ostracism' (Wrangham, 2014, 2018) hypotheses. For example, multiple influential contributions address the evolutionary benefits of enhanced human sociability and collaborative capacity (Sterelny, 2011, 2012), especially via cooperative reproductive efforts (Burkart et al., 2014; Hawkes, 2013; Hrdy, 2011). Additionally, the nature of human intersexual selection provides a flourishing field with numerous contributors (Archer, 2009; Brooks et al., 2010; DeBruine, Jones, Crawford, et al., 2010; Feinberg et al., 2008; Kruger, 2006; Lee et al., 2015; Thornhill, Chapman, \& Gangestad, 2013). The proposal that group ostracism and punishment could act as selection for domesticated sociability (Wrangham, 2014, 2018) mirrors work by Boehm $(2012,2014)$ and Pinker (2011), among others. And, finally, the suggestion that cooperative male sociability followed selection for reduced in-group rivalry to support collaborative competition and inter-group hostility (Alexander, 1990; Flinn et al., 2005; Wrangham \& Glowacki, 2012) provides another potentially domesticating influence.

From the Middle Pleistocene, human evolution has involved reduction, or significant change, in several biophysical indicators of masculinity, including skeletal robusticity, upper-body strength, and body size sexual dimorphism (Carrier \& Morgan, 2015; Frayer \& Wolpoff, 1985; Hill, Bailey, \& Puts, 2017; Lindenfors \& Tullberg, 2011; Ruff, 2002; Ryan \& Shaw, 2015), as well as craniofacial robusticity and prognathism (Carrier \& Morgan, 2015; Cieri et al., 2014). These physical changes coincide with an expansion of cultural and technological complexity, widely thought to indicate increased social tolerance and cooperative capacity (Boehm, 2014; Burkart et al., 2014; Cieri et al., 2014; Flinn et al., 2005; Hare, 2017; Hawkes, 2013; Hrdy, 2011; Sterelny, 2011). Whilst several hypotheses have been proposed to explain these evolutionary changes (Boehm, 2014; Burkart et al., 2014; Carrier \& Morgan, 2015; Flinn et al., 2005; Frayer, 1980; Frayer \& Wolpoff, 1985; Hill et al., 2017; Hrdy, 2011; Pinker, 2011), each is limited by the absence of specific biophysical mechanisms aside from 
Masculinity and the mechanisms of human self-domestication-Ben Gleeson

1 disparate selection for unspecified genes which might promote each trait in relative isolation.

2 Contrastingly, the correlated behavioural, physiological, and morphological changes

3 associated with domestication syndrome have been experimentally demonstrated, and

4 repeatedly confirmed across different species over a significant period (Belyaev, 1979; L.

5 Trut et al., 2006; L. N. Trut, 1999; L. N. Trut et al., 2009). As such, the self-domestication

6 process may offer a mechanistic foundation for multiple lines of research on selective

7 processes and change in recent human evolution.

8 One aspect of human evolution that must have significantly benefited lower levels of

9 masculinity, is the increasing altriciality of human infants (van Schaik, 2016; Zollikofer \&

10 Ponce de León, 2010). This trend would inevitably increase the relative fitness of capable

11 parental investors, certainly among cooperative female kin, and, to some extent, among males

12 as well (Hrdy, 2011). Reduced sexual dimorphism is a recurrent trait among cooperatively

13 breeding species (Clutton-Brock et al., 2006; Rubenstein \& Lovette, 2009) suggesting this

14 trend in humans might reflect increasing paternal investment. Coincident increase in human

15 social and communication complexity might also have enhanced the fitness of more sociable

16 paternal investors via group sanctions against particularly masculine reproductive behaviours,

17 including: extra-pair copulation, violent sexual coercion, and unwanted mate guarding.

18 Varying levels of female social status would also moderate the efficacy of the latter two

19 mating strategies, limiting their relative fitness wherever women exercised relative sexual

20 autonomy.

21 However, any intersexual selection operating in favour of more sociable, less-masculine,

22 males must have occurred in tandem with intra-sexual selection (forms of male-male

23 competition) often likely to exert a contrasting influence. Despite our noted trajectory of de-

24 masculinisation, humans remain a sexually dimorphic species in several characteristics, and multiple traits indicate past and continuing male competition (Carrier \& Morgan, 2015; Fink,

26 Weege, Manning, \& Trivers, 2014; Hill et al., 2017; Scott, Clark, Boothroyd, \& PentonVoak, 2013; Sell, Hone, E, \& Pound, 2012). Hill et al. (2017) have argued that apparent reduction in human sexual dimorphism is consistent with changes in intrasexual selection leading to enhanced same-sex intimidation, or 'formidability', instead of actual combat.

30 Certainly, moderation of in-group male-male competition would be a necessary precondition,

31 if, as has been suggested, increased human sociability required more collaborative forms of 
1 competition (Flinn et al., 2005; Hill et al., 2017), especially as violent intergroup hostility

2 (Wrangham \& Glowacki, 2012).

3 Considering all of the above, Table 3 provides a summary of mechanisms that might

4 influence processes of human self-domestication based on selection for decreased masculinity

5 and increased social and cooperative capacities. These are presented in the form of positive

6 and negative feedback which emphasises the interactions between multiple selective

7 pressures that must have varied across our evolutionary history.

8 Table 2: Selective feedbacks affecting human sociability, masculinity, and self-domestication.

Types of feedback Relevant influences

\begin{tabular}{|c|c|}
\hline \multirow{5}{*}{ Positive } & Increasing altriciality \\
\hline & Female preference for paternal investment \\
\hline & High population density and increased reliance on a sociocultural niche \\
\hline & Ostracism of aggressive individuals \\
\hline & Group collaboration in inter-group hostilities \\
\hline \multirow[t]{2}{*}{ Negative } & Direct male-male competition \\
\hline & Female selection in favour of masculine 'good genes' \\
\hline
\end{tabular}

7. Limitations, key questions, and directions for further research

10 A potential limitation to any empirical study of human self-domestication is the identification

11 of suitable comparators. Whilst this issue has been solved in the case of previous animal

12 breeding experiments, it almost goes without saying that such experiments are ethically,

13 morally, and practically impossible among humans. It follows that any study of human self-

14 domestication must rely on observational and comparative research of existing populations

15 alone. This should not be problematic since comparative research is easily as robust as

16 experimental work so long as suitable statistical controls are applied for potentially

17 confounding influences (Thornhill \& Fincher, 2013). In association with existing

18 experimental research on domesticated animals, comparative research on past and present

19 humans should adequately support further empirical study.

20 It must be noted, however, that comparisons may be problematic for other reasons. Since unique evolutionary selection and drift tend to operate on various traits in any given population, increasing phylogenetic distance means potential comparators should show many

23 changes unrelated to the mechanisms of domestication syndrome. For this reason, only

24 closely-related comparator lineages are likely to prove useful. In humans, comparisons

25 between distantly ancestral and modern populations indicate long-term directional change 
Masculinity and the mechanisms of human self-domestication-Ben Gleeson

1 suggestive of domestication syndrome (Cieri et al., 2014). These results demonstrate that all modern humans are relatively self-domesticated in comparison with earlier people. However, simple comparison of features known to vary between distantly-related modern populations will involve numerous confounding influences due to interceding cultural norms and environmental factors. Further, as with most comparisons of distant human groups, variation within populations is likely to exceed that observed via interpopulation comparisons, this is certainly true of relative masculinity, and is also likely regarding self-domestication. As such, temporal, socioeconomic, and cultural comparisons of closely related human lineages offer the most productive and rigorous comparisons for future investigation of this topic.

Possibly the most outstanding inconsistency raised by the hypothesis proposed in this article relates to the difference in relative testosterone level between less-masculine human males and domesticated male animals. The question is, if masculine traits are influenced in the same way as domesticated ones, why would testosterone tend to be lower in less-masculine men, but higher in domesticated animals? If domestication syndrome is effectively an expression of relatively dampened physiological masculinity, it seems we would expect lower testosterone in both less-masculine men and in domesticated taxa as compared to more masculine and non-domesticated comparators. As proposed earlier, it may be that levels of testosterone production are determined separately to the other, more structural, features of masculinity and that androgen receptors in NCC-derived tissues are the primary mode of variance in both masculinity and in domestication. However, whilst this possibility deemphasises the direct role of testosterone in human self-domestication, it remains a curiosity that testosterone levels would not appear to shift in the same direction in less-masculine selfdomesticated humans as they do in domesticated animals.

Another outstanding issue involves the regular lack of precise correlation across masculine traits in men. That is, if trait expression is reliably correlated in NCC-derived features, why would men show varying levels of masculinity in different features? For instance, why do some men have deep voices but not large jaws, and vice versa? Why do some show a facial dermis with potential for dense facial hair, but no propensity for reactive behaviour? This lack of correlation may well indicate a fundamental flaw in the hypothesis or might simply 30 demonstrate that perfect correlation is unlikely in biology. It may be that costly production of androgen receptors necessitates optimised distributions and that different lineages invest in different masculine signalling strategies. This issue would require further study. 
Masculinity and the mechanisms of human self-domestication-Ben Gleeson

1 To expand empirical investigation of human self-domestication, further research into the activity of NCCs, and the genetic, or epigenetic, factors that regulate their proliferation, are likely to prove insightful. A range of recent sources have considered the genetics of domestication syndrome and these may be utilised as foundations for further investigation (Benítez-Burraco, Lattanzi, \& Murphy, 2016; Benítez-Burraco, Pietro, Barba, \& Lattanzi, 2017; Benítez-Burraco, Theofanopoulou, \& Boeckx, 2016; Theofanopoulou et al., 2017; Wilkins et al., 2014; Wright, 2015). Note though that the findings of this present review suggest value in an expanded focus on genetic regulatory mechanisms associated with masculinity in general, and on androgen receptor densities in NCC-derived cells and tissues in particular. Due to the ubiquitous nature of vertebrate NCCs, useful investigation might initially progress via non-human research since the mechanisms involved in male secondary traits should influence embryonic NCCs across most vertebrate taxa.

Whilst Wilkens et al. (2014) drew links between the domestication process and pathological features common to various forms of neurocristopathy, other researchers have investigated similarities between domestication and pathologies associated with variation in the language centres of the human brain. These suggest that both autism spectrum disorder and schizophrenia could occur in response to physiological activity related to mechanisms of selfdomestication (Benítez-Burraco, 2017; Benítez-Burraco, Lattanzi, et al., 2016; BenítezBurraco et al., 2017). Recent demonstration of craniofacial hypermasculinisation associated with autism spectrum disorder (Tan et al., 2017) — a syndrome disproportionately associated with human males - may prove directly relevant in light of the relationship between domestication and masculine phenotypes proposed in the present article. These connections might suggest productive investigation of testosterone-moderating developmental interventions targeted towards several autism related symptoms. Apart from facial hypermasculinisation, a link between self-domestication and autism would predict for other correlated symptoms including larger brains and adrenal systems in autistic individuals.

A further useful focus for expanded research in domestication and human self-domestication would be to conclusively demonstrate underlying mechanisms causing noted hypoplasia of NCC-derived tissues in domesticates. If moderated in-situ proliferation or growth of NCCs in response to testosterone presence were the general mechanism of domestication, then further work is required to determine exactly why, and by what means, this interaction occurs. Based on combination of suggestions provided by Wilkins et al. (2014) and Cieri et al. (2014), this 
1 article has hypothesised inherited modification of androgen receptor densities within NCCs, or NCC-derived tissues, as an influential mechanism. Having said this, endocrine interactions

3 involved in the regulation and metabolism of testosterone are highly complex, and further investigation of these relationships will be required. The specific influence of NCC-derived cells in the pituitary upon the operation of the HPG axis and its active role in testosterone production also remains to be considered and thoroughly explored, especially in light of the inconsistencies between masculine men and male domesticates, noted above.

8 The observations presented in this article offer potential for further productive research by a range of methods appropriate to multiple fields of investigation. Table 4 specifies several initial predictions that might stimulate further examination and testing of domesticationrelated mechanisms.

Table 3: Six predictions derived from hypothesised mechanisms presented here.

\begin{abstract}
1) Androgen receptor densities within NCC-derived tissues should vary between relatively domesticated and non-domesticated lineages and between high and low masculinity individuals, with the domestic/low state showing relative reduction.
\end{abstract}

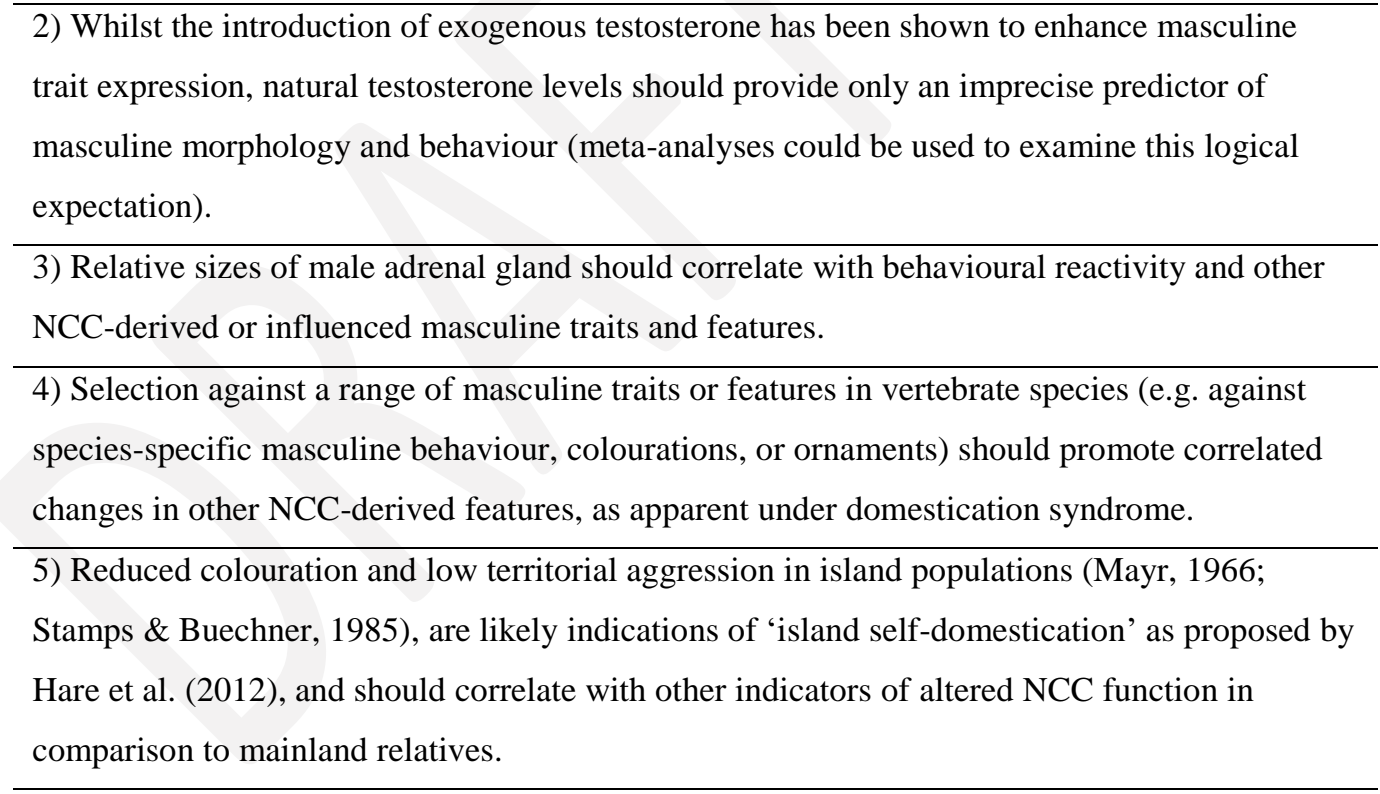

6) NCC-derived structures (e.g. the hyoid, see: Torimitsu et al., 2017) should prove particularly useful for accurate sex determination within populations of related individuals.

\title{
8. Conclusion
}

14 Across multiple taxa, numerous signals of masculinity result from embryonic neural crest cell progenitors. Since domestication syndrome occurs as a biophysical response to selection for sociability and involves correlated change in numerous NCC-derived tissues, correlations 
Masculinity and the mechanisms of human self-domestication-Ben Gleeson

1 with longstanding interest in the processes of domestication, and human self-domestication.

2 These connections might help to inform further investigation of varying female preference for

3 masculine features in multiple vertebrate taxa (i.e. by extending 'handicap' and 'costly

4 signalling' studies). In a wider sense, the mechanisms of testosterone-mediated NCC

5 proliferation and growth may promote a range of further investigation and discussion around

6 masculine morphology, physiology and behaviour.

7 The self-domestication of Homo sapiens has been characterized as a necessary process in our

8 evolution towards a more cooperative and sociable form; promoting the development of

9 human culture, knowledge sharing, and dramatic technological advance (Cieri et al., 2014;

10 Hare, 2017). The increased collaborative capacity and cooperation enabled by this process

11 allowed for the emergence of humanity's complex and constructed 'social-niche'-based mode

12 of existence (e.g. see: Ellis, 2015; Odling-Smee, Laland, \& Feldman, 2003; Sterelny, 2011).

13 Given the relatively recent increase in social and technological complexity accompanying the

14 emergence of human civilizations, the strongest impacts of this process have emerged only

15 lately in our evolution. This might imply human self-domestication is a continuing (even

16 accelerating) process. However, the complex range of influential biological, cultural, and environmental factors occurring within modern society make any overall trend difficult to predict. Further research regarding selection on human masculinity should proceed with an enhanced paradigmatic foundation via reference to testosterone-mediated NCC proliferation, and a broader understanding of its effects upon human biology and behaviour, as individuals, and as a society.

Acknowledgements

References

26 Alberch, P., Gould, S. J., Oster, G. F., \& Wake, D. B. (1979). Size and shape in ontogeny and phylogeny. Paleobiology, 5(3), 296-317. https://doi.org/10.1017/S0094837300006588 
Masculinity and the mechanisms of human self-domestication-Ben Gleeson

1 Alvergne, A., Faurie, C., \& Raymond, M. (2009). Variation in testosterone levels and male reproductive effort: Insight from a polygynous human population. Hormones and Behavior, 56(5), 491-497. https://doi.org/10.1016/j.yhbeh.2009.07.013

Archer, J. (2009). Does sexual selection explain human sex differences in aggression? Behavioral and Brain Sciences, 32(3-4), 249-66; discussion 266-311. https://doi.org/http://dx.doi.org.virtual.anu.edu.au/10.1017/S0140525X09990951

Balolia, K. L., Soligo, C., \& Lockwood, C. A. (2013). Sexual Dimorphism and Facial Growth Beyond Dental Maturity in Great Apes and Gibbons. International Journal of Primatology, 34(2), 361-387. https://doi.org/10.1007/s10764-013-9666-z

Balolia, K. L., Soligo, C., \& Wood, B. (2017). Sagittal crest formation in great apes and gibbons. Journal of Anatomy, 230(6), 820-832. https://doi.org/10.1111/joa.12609

Barrett, R. L., \& Harris, E. F. (1993). Anabolic steroids and craniofacial growth in the rat. The Angle Orthodontist, 63(4), 289-298. https://doi.org/10.1043/00033219(1993)063<0289:ASACGI>2.0.CO;2

Belyaev, D. K. (1979). Destabilizing selection as a factor in domestication. Journal of Heredity, 70(5), 301-308.

Benítez-Burraco, A. (2017). Grammaticalization and language evolution: Focusing the debate. Language Sciences, 63(Supplement C), 60-68. https://doi.org/10.1016/j.langsci.2017.03.003

Benítez-Burraco, A., Lattanzi, W., \& Murphy, E. (2016). Language Impairments in ASD Resulting from a Failed Domestication of the Human Brain. Frontiers in Neuroscience, 10. https://doi.org/10.3389/fnins.2016.00373 and Evolution, 89(3), 162-184. https://doi.org/10.1159/000468506 
Masculinity and the mechanisms of human self-domestication-Ben Gleeson

1 Benítez-Burraco, A., Theofanopoulou, C., \& Boeckx, C. (2016). Globularization and Domestication. Topoi, 1-14. https://doi.org/10.1007/s11245-016-9399-7

Bhatt, S., Diaz, R., \& Trainor, P. A. (2013). Signals and Switches in Mammalian Neural Crest Cell Differentiation. Cold Spring Harbor Perspectives in Biology, 5(2). https://doi.org/10.1101/cshperspect.a008326

Boehm, C. (2012). Moral Origins: The Evolution of Virtue, Altruism, and Shame. Basic Books.

Boehm, C. (2014). The moral consequences of social selection. Behaviour, 151(2-3), 167183. https://doi.org/10.1163/1568539X-00003143

Boothroyd, L. G., Gray, A. W., Headland, T. N., Uehara, R. T., Waynforth, D., Burt, D. M., \& Pound, N. (2017). Male Facial Appearance and Offspring Mortality in Two Traditional Societies. PLoS One; San Francisco, 12(1). https://doi.org/http://dx.doi.org/10.1371/journal.pone.0169181

Brace, C. L., Rosenberg, K. R., \& Hunt, K. D. (1987). Gradual Change in Human Tooth Size in the Late Pleistocene and Post- Pleistocene. Evolution, 41(4), 705-720. https://doi.org/10.2307/2408882

Brace, C. L., \& Ryan, A. S. (1980). Sexual dimorphism and human tooth size differences. Journal of Human Evolution, 9(5), 417-435. https://doi.org/10.1016/00472484(80)90051-2

Brooks, R., Scott, I. M., Maklakov, A. A., Kasumovic, M. M., Clark, A. P., \& Penton-Voak, I. S. (2010). National income inequality predicts women's preferences for masculinized faces better than health does. Proceedings of the Royal Society of London B: Biological Sciences, rspb20100964. https://doi.org/10.1098/rspb.2010.0964 
Masculinity and the mechanisms of human self-domestication-Ben Gleeson

1 Brüne, M. (2007). On human self-domestication, psychiatry, and eugenics. Philosophy, Ethics, and Humanities in Medicine, 2(1), 21. https://doi.org/10.1186/1747-5341-2-21

Burkart, J. M., Allon, O., Amici, F., Fichtel, C., Finkenwirth, C., Heschl, A., ... van Schaik, C. P. (2014). The evolutionary origin of human hyper-cooperation. Nature Communications, 5, 4747. https://doi.org/10.1038/ncomms5747

Burkart, J. M., Hrdy, S. B., \& Van Schaik, C. P. (2009). Cooperative breeding and human cognitive evolution. Evolutionary Anthropology: Issues, News, and Reviews, 18(5), 175-186. https://doi.org/10.1002/evan.20222

Burnham, T. ., Chapman, J. F., Gray, P. ., McIntyre, M. ., Lipson, S. ., \& Ellison, P. . (2003). Men in committed, romantic relationships have lower testosterone. Hormones and Behavior, 44(2), 119-122. https://doi.org/10.1016/S0018-506X(03)00125-9

Calcagno, J. M., \& Gibson, K. R. (1988). Human dental reduction: Natural selection or the probable mutation effect. American Journal of Physical Anthropology, 77(4), 505517. https://doi.org/10.1002/ajpa.1330770411

Carré, J. M., McCormick, C. M., \& Mondloch, C. J. (2009). Facial Structure Is a Reliable Cue of Aggressive Behavior. Psychological Science, 20(10), 1194-1198. https://doi.org/10.1111/j.1467-9280.2009.02423.x

Carrier, D. R., \& Morgan, M. H. (2015). Protective buttressing of the hominin face. Biological Reviews, 90(1), 330-346. https://doi.org/10.1111/brv.12112

Cieri, R. L., Churchill, S. E., Franciscus, R. G., Tan, J., \& Hare, B. (2014). Craniofacial Feminization, Social Tolerance, and the Origins of Behavioral Modernity. Current Anthropology, 55(4), 419-443. https://doi.org/10.1086/677209

Clutton-Brock, T. H., Hodge, S. J., Spong, G., Russell, A. F., Jordan, N. R., Bennett, N. C., ... Manser, M. B. (2006). Intrasexual competition and sexual selection in cooperative 
Masculinity and the mechanisms of human self-domestication-Ben Gleeson mammals. Nature; London, 444(7122), 1065-1068. https://doi.org/http://dx.doi.org.virtual.anu.edu.au/10.1038/nature05386

Cordero, D. R., Brugmann, S., Chu, Y., Bajpai, R., Jame, M., \& Helms, J. A. (2011). Cranial neural crest cells on the move: Their roles in craniofacial development. American Journal of Medical Genetics Part A, 155(2), 270-279. https://doi.org/10.1002/ajmg.a.33702

Darwin, C. (1859). On the Origin of Species by Means of Natural Selection, Or, The Preservation of Favoured Races in the Struggle for Life. London: John Murray.

Darwin, C. (1868). The variation of animals and plants under domestication. London: John Murray.

Darwin, C. (1871). The descent of man: and selection in relation to sex. London.

Davis, E. B., Brakora, K. A., \& Lee, A. H. (2011). Evolution of ruminant headgear: a review. Proceedings: Biological Sciences, 278(1720), 2857-2865.

DeBruine, L. M., Jones, B. C., Crawford, J. R., Welling, L. L. M., \& Little, A. C. (2010). The health of a nation predicts their mate preferences: cross-cultural variation in women's preferences for masculinized male faces. Proceedings of the Royal Society B: Biological Sciences, 277(1692), 2405-2410. https://doi.org/10.1098/rspb.2009.2184

DeBruine, L. M., Jones, B. C., Frederick, D. A., Haselton, M. G., Penton-Voak, I. S., \& Perrett, D. I. (2010). Evidence for Menstrual Cycle Shifts in Women's Preferences for Masculinity: A Response to Harris (in Press) "Menstrual Cycle and Facial Preferences Reconsidered.” Evolutionary Psychology, 8(4), 147470491000800420. https://doi.org/10.1177/147470491000800416

Dixson, B. J. (2016). Masculinity and Femininity. In T. K. Shackelford \& V. A. WeekesShackelford (Eds.), Encyclopedia of Evolutionary Psychological Science. Springer International Publishing. Retrieved from DOI 10.1007/978-3-319-16999-6_3389-1 
Masculinity and the mechanisms of human self-domestication-Ben Gleeson

1 Dixson, B. J., \& Brooks, R. C. (2013). The role of facial hair in women's perceptions of men's attractiveness, health, masculinity and parenting abilities. Evolution and Human Behavior, 34(3), 236-241. https://doi.org/10.1016/j.evolhumbehav.2013.02.003

Dixson, B. J., Lee, A. J., Sherlock, J. M., \& Talamas, S. N. (2017). Beneath the beard: do facial morphometrics influence the strength of judgments of men's beardedness? Evolution and Human Behavior, 38(2), 164-174. https://doi.org/10.1016/j.evolhumbehav.2016.08.004

Dixson, B. J., Rantala, M. J., Melo, E. F., \& Brooks, R. C. (2017). Beards and the big city: displays of masculinity may be amplified under crowded conditions. Evolution and Human Behavior, 38(2), 259-264. https://doi.org/10.1016/j.evolhumbehav.2016.10.009

Dubuc, C., Allen, W. L., Maestripieri, D., \& Higham, J. P. (2014). Is male rhesus macaque red color ornamentation attractive to females? Behavioral Ecology and Sociobiology, 68(7), 1215-1224. https://doi.org/10.1007/s00265-014-1732-9

Dunkel, L. P., Arora, N., van Noordwijk, M. A., Atmoko, S. S. U., Putra, A. P., Krützen, M., \& van Schaik, C. P. (2013). Variation in developmental arrest among male orangutans: a comparison between a Sumatran and a Bornean population. Frontiers in Zoology, 10, 12. https://doi.org/10.1186/1742-9994-10-12

Ellis, E. C. (2015). Ecology in an anthropogenic biosphere. Ecological Monographs, 85(3), 287-331. https://doi.org/10.1890/14-2274.1

Ericsson, R., Knight, R., \& Johanson, Z. (2013). Evolution and development of the vertebrate neck. Journal of Anatomy, 222(1), 67-78. https://doi.org/10.1111/j.14697580.2012.01530.x 
Masculinity and the mechanisms of human self-domestication-Ben Gleeson

1 Evans, M. R., Goldsmith, A. R., \& Norris, S. R. A. (2000). The Effects of Testosterone on Antibody Production and Plumage Coloration in Male House Sparrows (Passer domesticus). Behavioral Ecology and Sociobiology, 47(3), 156-163. https://doi.org/10.2307/4601725

Feinberg, D. R., DeBruine, L. M., Jones, B. C., \& Little, A. C. (2008). Correlated preferences for men's facial and vocal masculinity. Evolution and Human Behavior, 29(4), 233241. https://doi.org/10.1016/j.evolhumbehav.2007.12.008

Fink, B., Weege, B., Manning, J. T., \& Trivers, R. (2014). Body symmetry and physical strength in human males: Body Symmetry and Physical Strength in Human MaleS. American Journal of Human Biology, 26(5), 697-700. https://doi.org/10.1002/ajhb.22584

Fischer, E. (1914). Die Rassenmerkmale des Menschen als Domesticationserscheinungen. Zeitschrift Für Morphologie Und Anthropologie, 18, 479-524.

Flinn, M. V., Geary, D. C., \& Ward, C. V. (2005). Ecological dominance, social competition, and coalitionary arms races: Why humans evolved extraordinary intelligence. Evolution and Human Behavior, 26(1), 10-46. https://doi.org/10.1016/j.evolhumbehav.2004.08.005

Franciscus, R. G., Maddux, S. D., \& Schmidt, K. W. (2013). Anatomically modern humans as a "self-domesticated" species: insights from ancestral wolves and descendant dogs. Presented at the 82nd Annual Meeting of the American Association of Physical Anthropologists, Knoxville, Tennessee, Knoxville, Tennessee.

Frayer, D. W. (1980). Sexual dimorphism and cultural evolution in the Late Pleistocene and Holocene of Europe. Journal of Human Evolution, 9(5), 399-415. https://doi.org/10.1016/0047-2484(80)90050-0 
Masculinity and the mechanisms of human self-domestication-Ben Gleeson

1 Frayer, D. W., \& Wolpoff, M. H. (1985). Sexual Dimorphism. Annual Review of Anthropology, 14(1), 429-473. https://doi.org/10.1146/annurev.an.14.100185.002241

3 Furuichi, T. (2011). Female contributions to the peaceful nature of bonobo society. Evolutionary Anthropology, 20(4), 131-142. https://doi.org/10.1002/evan.20308

5 Gangestad, S. W., \& Thornhill, R. (2008). Human Oestrus. Proceedings: Biological Sciences, 275(1638), 991-1000.

7 Gilbert, S. F. (2010). Developmental biology (9th ed). Sunderland, MA: Sinauer Associates.

8 Gould, S. J. (1966). Allometry and Size in Ontogeny and Phylogeny. Biological Reviews, 41(4), 587-638. https://doi.org/10.1111/j.1469-185X.1966.tb01624.x

10 Gould, S. J. (1977). Ontogeny and Phylogeny. Cambridge, Mass.: Harvard University Press. Retrieved from http://www.hup.harvard.edu/catalog.php?isbn=9780674639416

Groves, C. (1989). A Theory of Human and Primate Evolution. Oxford and New York: Oxford University Press, USA.

Groves, C. (1999). The advantages and disadvantages of being domesticated. Perspectives in Human Biology, 4(1), 1-12.

Hall, B. K. (2000). The neural crest as a fourth germ layer and vertebrates as quadroblastic not triploblastic. Evolution \& Development, 2(1), 3-5. https://doi.org/10.1046/j.1525$142 \mathrm{x} .2000 .00032 . \mathrm{x}$

Hall, B. K. (2008). The neural crest and neural crest cells: discovery and significance for theories of embryonic organization. Journal of Biosciences; Dordrecht, 33(5), 781793. https://doi.org/http://dx.doi.org.virtual.anu.edu.au/10.1007/s12038-008-0098-4

Hall, J. E. (2010). Guyton and Hall Textbook of Medical Physiology (12th edition). Philadelphia, Pa: Saunders. 
Masculinity and the mechanisms of human self-domestication-Ben Gleeson

1 Hare, B. (2017). Survival of the Friendliest: Homo sapiens Evolved via Selection for Prosociality. Annual Review of Psychology, 68(1). https://doi.org/10.1146/annurevpsych-010416-044201

Hare, B., Wobber, V., \& Wrangham, R. W. (2012). The self-domestication hypothesis: Evolution of bonobo psychology is due to selection against aggression. Animal Behaviour, 83(3), 573-585. https://doi.org/10.1016/j.anbehav.2011.12.007

Harris, C. R. (2013). Shifts in Masculinity Preferences Across the Menstrual Cycle: Still Not There. Sex Roles; New York, 69(9-10), 507-515. https://doi.org/http://dx.doi.org.virtual.anu.edu.au/10.1007/s11199-012-0229-0

Hawkes, K. (2013). Primate Sociality to Human Cooperation: Why Us and Not Them? Human Nature, 25(1), 28-48. https://doi.org/10.1007/s12110-013-9184-X

Heck, H. (1951). The Breeding-Back of the Aurochs. Oryx, 1(3), 117-122. https://doi.org/10.1017/S0030605300035286

Helmer, D., Goucherin, L., Monchot, H., Peters, J., \& Sana Segui, M. (2002). Identifying domestic cattle from early Neolithic sites on the Middle Euphrates with the help of sex determination. In J. D. Vigne, J. Peters, \& D. Helmer (Eds.), The First Steps of Animal Domestication (pp. 86-95). Durham: Oxbow Books.

Hemmer, H. (1990). Domestication: The Decline of Environmental Appreciation. Cambridge, U.K.: Cambridge University Press.

Henneberg, M. (1988). Decrease of Human Skull Size in the Holocene. Human Biology, 60(3), 395-405.

Henneberg, M., \& Steyn, M. (1993). Trends in cranial capacity and cranial index in 
Masculinity and the mechanisms of human self-domestication-Ben Gleeson

1 Hill, A. K., Bailey, D. H., \& Puts, D. A. (2017). Chapter 15 - Gorillas in Our Midst? Human Sexual Dimorphism and Contest Competition in Men. In F. J. Ayala (Ed.), On Human Nature (pp. 235-249). San Diego: Academic Press. Retrieved from http://www.sciencedirect.com/science/article/pii/B9780124201903000156

Hodges-Simeon, C. R., Sobraske, K. N. H., Samore, T., Gurven, M., \& Gaulin, S. J. C. (2016). Facial Width-To-Height Ratio (fWHR) Is Not Associated with Adolescent Testosterone Levels. PLOS ONE, 11(4), e0153083. https://doi.org/10.1371/journal.pone.0153083

Hrdy, S. B. (2011). Mothers and Others: The Evolutionary Origins of Mutual Understanding. Cambridge, Mass.: The Belknap Press.

Jensen, P. (2006). Domestication—From behaviour to genes and back again. Applied Animal Behaviour Science, 97(1), 3-15. https://doi.org/10.1016/j.applanim.2005.11.015

Jinno, H., Morozova, O., Jones, K. L., Biernaskie, J. A., Paris, M., Hosokawa, R., ... Miller, F. D. (2010). Convergent Genesis of an Adult Neural Crest-Like Dermal Stem Cell

Kappelman, J. (1996). The evolution of body mass and relative brain size in fossil hominids. Journal of Human Evolution, 30(3), 243-276. https://doi.org/10.1006/jhev.1996.0021

Katz, L. S. (2007). Sexual behavior of domesticated ruminants. Hormones and Behavior, 52(1), 56-63. https://doi.org/10.1016/j.yhbeh.2007.03.012

Knight, R. D., \& Schilling, T. F. (2013). Cranial Neural Crest and Development of the Head Skeleton. Landes Bioscience. Retrieved from https://www.ncbi.nlm.nih.gov/books/NBK6075/

Krause, M. P., Dworski, S., Feinberg, K., Jones, K., Johnston, A. P. W., Paul, S., ... Miller, F. D. (2014). Direct Genesis of Functional Rodent and Human Schwann Cells from 
Masculinity and the mechanisms of human self-domestication-Ben Gleeson

Skin Mesenchymal Precursors. Stem Cell Reports, 3(1), 85-100. https://doi.org/10.1016/j.stemcr.2014.05.011

Kruger, D. J. (2006). Male facial masculinity influences attributions of personality and reproductive strategy. Personal Relationships, 13(4), 451-463. https://doi.org/10.1111/j.1475-6811.2006.00129.x

Kruska, D. (1988). Mammalian Domestication and its Effect on Brain Structure and Behavior. In H. J. Jerison \& I. Jerison (Eds.), Intelligence and Evolutionary Biology (pp. 211-250). Springer Berlin Heidelberg. https://doi.org/10.1007/978-3-642-70877$0 \_13$

Künzl, C., \& Sachser, N. (1999). The Behavioral Endocrinology of Domestication: A Comparison between the Domestic Guinea Pig (Cavia apereaf.porcellus) and Its Wild Ancestor, the Cavy (Cavia aperea). Hormones and Behavior, 35(1), 28-37. https://doi.org/10.1006/hbeh.1998.1493

Leach, H. M. (2003). Human Domestication Reconsidered. Current Anthropology, 44(3), 349-368. https://doi.org/10.1086/368119

Leach, H. M. (2007). Selection and the Unforeseen Consequences of Domestication. In Where the Wild Things Are Now: Domestication Reconsidered. Oxford and New York: Berg.

Lee, A. J., Brooks, R. C., Potter, K. J., \& Zietsch, B. P. (2015). Pathogen disgust sensitivity and resource scarcity are associated with mate preference for different waist-to-hip ratios, shoulder-to-hip ratios, and body mass index. Evolution and Human Behavior, 36(6), 480-488. https://doi.org/10.1016/j.evolhumbehav.2015.07.002

Lefevre, C. E., Lewis, G. J., Perrett, D. I., \& Penke, L. (2013). Telling facial metrics: facial width is associated with testosterone levels in men. Evolution and Human Behavior, 34(4), 273-279. https://doi.org/10.1016/j.evolhumbehav.2013.03.005 
Masculinity and the mechanisms of human self-domestication-Ben Gleeson

1 Lincoln, G. A., Lincoln, C. E., \& McNeilly, A. S. (1990). Seasonal cycles in the blood plasma concentration of FSH, inhibin and testosterone, and testicular size in rams of wild, feral and domesticated breeds of sheep. Journal of Reproduction and Fertility, 88(2), 623-633. https://doi.org/10.1530/jrf.0.0880623

Lindenfors, P., \& Tullberg, B. S. (2011). Evolutionary Aspects of Aggression. Aggression, 75, 7-22. https://doi.org/10.1016/B978-0-12-380858-5.00009-5

Little, A. C., Connely, J., Feinberg, D. R., Jones, B. C., \& Roberts, S. C. (2011). Human preference for masculinity differs according to context in faces, bodies, voices, and smell. Behavioral Ecology, 22(4), 862-868. https://doi.org/10.1093/beheco/arr061

Little, A. C., DeBruine, L. M., \& Jones, B. C. (2010). Exposure to visual cues of pathogen contagion changes preferences for masculinity and symmetry in opposite-sex faces. Proceedings of the Royal Society of London B: Biological Sciences, rspb20101925. https://doi.org/10.1098/rspb.2010.1925

Little, A. C., Jones, B. C., \& Burriss, R. P. (2007). Preferences for masculinity in male bodies change across the menstrual cycle. Hormones and Behavior, 51(5), 633-639. https://doi.org/10.1016/j.yhbeh.2007.03.006

Little, A. C., Saxton, T. K., Roberts, S. C., Jones, B. C., DeBruine, L. M., Vukovic, J., ... Chenore, T. (2010). Women's preferences for masculinity in male faces are highest during reproductive age range and lower around puberty and post-menopause. Psychoneuroendocrinology, 35(6), 912-920. https://doi.org/10.1016/j.psyneuen.2009.12.006

Liu, C., Tang, Y., Ge, H., Wang, F., Sun, H., Meng, H., ... Liu, S. (2014). Increasing breadth of the frontal lobe but decreasing height of the human brain between two Chinese samples from a Neolithic site and from living humans. American Journal of Physical Anthropology, 154(1), 94-103. https://doi.org/10.1002/ajpa.22476 
Masculinity and the mechanisms of human self-domestication-Ben Gleeson

1 Lorenz, K. (1940). Durch Domestikation verursachte Störungen arteigenen Verhaltens. Z Angw Psychol Charakterk, 59, 2-81.

Marečková, K., Weinbrand, Z., Chakravarty, M. M., Lawrence, C., Aleong, R., Leonard, G., ... Paus, T. (2011). Testosterone-mediated sex differences in the face shape during adolescence: Subjective impressions and objective features. Hormones and Behavior, 60(5), 681-690. https://doi.org/10.1016/j.yhbeh.2011.09.004

Marshall, F. B., Dobney, K., Denham, T., \& Capriles, J. M. (2014). Evaluating the roles of directed breeding and gene flow in animal domestication. Proceedings of the National Academy of Sciences, 111(17), 6153-6158. https://doi.org/10.1073/pnas.1312984110

Matsuoka, T., Ahlberg, P. E., Kessaris, N., Iannarelli, P., Dennehy, U., Richardson, W. D., ... Koentges, G. (2005). Neural Crest Origins of the Neck and Shoulder. Nature, 436(7049), 347-355. https://doi.org/10.1038/nature03837

Mayr, E. (1966). Animal Species and Evolution. Caimbridge, Massachusetts: Harvard University Press. Retrieved from http://www.hup.harvard.edu/catalog.php?isbn=9780674865327

McGonnell, I. M., McKay, I. J., \& Graham, A. (2001). A Population of Caudally Migrating Cranial Neural Crest Cells: Functional and Evolutionary Implications. Developmental Biology, 236(2), 354-363. https://doi.org/10.1006/dbio.2001.0330

Mishina, Y., \& Snider, T. N. (2014). Neural crest cell signaling pathways critical to cranial bone development and pathology. Experimental Cell Research, 325(2), 138-147. https://doi.org/10.1016/j.yexcr.2014.01.019

Mitteroecker, P., Windhager, S., Müller, G. B., \& Schaefer, K. (2015). The Morphometrics of “Masculinity” in Human Faces: e0118374. PLoS One, 10(2). https://doi.org/http://dx.doi.org/10.1371/journal.pone.0118374 
Masculinity and the mechanisms of human self-domestication-Ben Gleeson

1 Noden, D. M. (1986). Patterning of avian craniofacial muscles. Developmental Biology, 116(2), 347-356. https://doi.org/10.1016/0012-1606(86)90138-7

3

Odling-Smee, F. J., Laland, K. N., \& Feldman, M. W. (2003). Niche Construction: The Neglected Process in Evolution. Princeton: Princeton University Press.

Penton-Voak, I. S., \& Chen, J. Y. (2004). High salivary testosterone is linked to masculine male facial appearance in humans. Evolution and Human Behavior, 25(4), 229-241. https://doi.org/10.1016/j.evolhumbehav.2004.04.003

Penton-Voak, I. S., Perrett, D. I., Castles, D. L., Kobayashi, T., Burt, D. M., Murray, L. K., \& Minamisawa, R. (1999). Menstrual cycle alters face preference. Nature, 399(6738), 741-742. https://doi.org/10.1038/21557

Pinker, S. (2011). The Better Angels of our Nature. New York: Viking.

Prum, R. O., \& Torres, R. H. (2004). Structural colouration of mammalian skin: convergent evolution of coherently scattering dermal collagen arrays. Journal of Experimental Biology, 207(12), 2157-2172. https://doi.org/10.1242/jeb.00989

Puts, D. A., Gaulin, S., \& Verdolini, K. (2006). Dominance and the evolution of sexual dimorphism in human voice pitch. Evolution and Human Behavior, 27(4), 283-296. https://doi.org/10.1016/j.evolhumbehav.2005.11.003

Puts, D. A., Hill, A. K., Bailey, D. H., Walker, R. S., Rendall, D., Wheatley, J. R., ... RamosFernandez, G. (2016). Sexual selection on male vocal fundamental frequency in humans and other anthropoids. Proc. R. Soc. B, 283(1829), 20152830. https://doi.org/10.1098/rspb.2015.2830

Puts, D. A., Jones, B. C., \& DeBruine, L. M. (2012). Sexual Selection on Human Faces and Voices. The Journal of Sex Research, 49(2-3), 227-243. https://doi.org/10.1080/00224499.2012.658924 
Masculinity and the mechanisms of human self-domestication-Ben Gleeson

1 Quist, M. C., Watkins, C. D., Smith, F. G., Little, A. C., Debruine, L. M., \& Jones, B. C.

(2012). Sociosexuality Predicts Women's Preferences for Symmetry in Men's Faces. Archives of Sexual Behavior; New York, 41(6), 1415-1421. https://doi.org/http://dx.doi.org/10.1007/s10508-011-9848-8

Rubenstein, D. R., \& Lovette, I. J. (2009). Reproductive skew and selection on female ornamentation in social species. Nature; London, 462(7274), 786-789.

Ruff, C. (2002). Variation in human body size and shape. Annual Review of Anthropology, $31,211-232$.

Ruff, C., Trinkaus, E., \& Holliday, T. W. (1997). Body mass and encephalization in Pleistocene Homo. Nature, 387(6629), 173-176. https://doi.org/10.1038/387173a0

Ryan, T. M., \& Shaw, C. N. (2015). Gracility of the modern Homo sapiens skeleton is the result of decreased biomechanical loading. Proceedings of the National Academy of Sciences, 112(2), 372-377. https://doi.org/10.1073/pnas.1418646112

Sánchez-Villagra, M. R., Geiger, M., \& Schneider, R. A. (2016). The taming of the neural crest: a developmental perspective on the origins of morphological covariation in domesticated mammals. Open Science, 3(6), 160107. https://doi.org/10.1098/rsos.160107

Santagati, F., \& Rijli, F. M. (2003). Cranial neural crest and the building of the vertebrate head. Nature Reviews. Neuroscience; London, 4(10), 806-818. https://doi.org/http://dx.doi.org.virtual.anu.edu.au/10.1038/nrn1221

Schoenwolf, G. C., Bleyl, S. B., Brauer, P. R., \& Francis-West, P. H. (2008). Larsen's Human Embryology (4 edition). Philadelphia: Churchill Livingstone.

Scott, I. M. L., Clark, A. P., Boothroyd, L. G., \& Penton-Voak, I. S. (2013). Do men's faces really signal heritable immunocompetence? Behavioral Ecology, 24(3), 579-589. https://doi.org/10.1093/beheco/ars092 
Masculinity and the mechanisms of human self-domestication-Ben Gleeson

1 Sell, A., Hone, L. S., E, \& Pound, N. (2012). The Importance of Physical Strength to Human Males. Human Nature: An Interdisciplinary Biosocial Perspective; New York, 23(1), 30-44. https://doi.org/http://dx.doi.org.virtual.anu.edu.au/10.1007/s12110-012-9131-2

Setchell, J. M., \& Dixson, A. F. (2001). Changes in the Secondary Sexual Adornments of Male Mandrills (Mandrillus sphinx) Are Associated with Gain and Loss of Alpha Status. Hormones and Behavior, 39(3), 177-184. https://doi.org/10.1006/hbeh.2000.1628

Shea, B. T. (1989). Heterochrony in human evolution: The case for neoteny reconsidered. American Journal of Physical Anthropology, 32(S10), 69-101. https://doi.org/10.1002/ajpa.1330320505

Stamps, J. A., \& Buechner, M. (1985). The Territorial Defense Hypothesis and the Ecology of Insular Vertebrates. The Quarterly Review of Biology, 60(2), 155-181.

Sterelny, K. (2011). From hominins to humans: how sapiens became behaviourally modern. Philosophical Transactions of the Royal Society B: Biological Sciences, 366(1566), 809-822. https://doi.org/10.1098/rstb.2010.0301

Sterelny, K. (2012). The Evolved Apprentice. Caimbridge, MA: MIT Press.

Surbeck, M., Deschner, T., Schubert, G., Weltring, A., \& Hohmann, G. (2012). Mate competition, testosterone and intersexual relationships in bonobos, Pan paniscus. Animal Behaviour, 83(3), 659-669. https://doi.org/10.1016/j.anbehav.2011.12.010

Tan, D. W., Gilani, S. Z., Maybery, M. T., Mian, A., Hunt, A., Walters, M., \& Whitehouse, A. J. O. (2017). Hypermasculinised facial morphology in boys and girls with Autism Spectrum Disorder and its association with symptomatology. Scientific Reports, 7(1), 9348. https://doi.org/10.1038/s41598-017-09939-y

Theofanopoulou, C., Gastaldon, S., O’Rourke, T., Samuels, B. D., Messner, A., Martins, P. T., ... Boeckx, C. (2017). Self-domestication in Homo sapiens: Insights from 
Masculinity and the mechanisms of human self-domestication-Ben Gleeson comparative genomics. PLoS One; San Francisco, 12(10), e0185306. https://doi.org/http://dx.doi.org.virtual.anu.edu.au/10.1371/journal.pone.0185306

Thompson, M. E., Zhou, A., \& Knott, C. D. (2012). Low Testosterone Correlates with Delayed Development in Male Orangutans. PLOS ONE, 7(10), e47282. https://doi.org/10.1371/journal.pone.0047282

Thornhill, R., Chapman, J. F., \& Gangestad, S. W. (2013). Women's preferences for men's scents associated with testosterone and cortisol levels: Patterns across the ovulatory cycle. Evolution and Human Behavior, 34(3), 216-221. https://doi.org/10.1016/j.evolhumbehav.2013.01.003

Thornhill, R., \& Fincher, C. L. (2013). The Comparative Method in Cross-Cultural and Cross-Species Research. Evolutionary Biology, 40(4), 480-493. https://doi.org/10.1007/s11692-013-9239-2

Tokuyama, N., \& Furuichi, T. (2016). Do friends help each other? Patterns of female coalition formation in wild bonobos at Wamba. Animal Behaviour, 119, 27-35. https://doi.org/10.1016/j.anbehav.2016.06.021

Torimitsu, S., Makino, Y., Saitoh, H., Ishii, N., Yajima, D., Inokuchi, G., ... Iwase, H. (2017). Determination of sex on the basis of hyoid bone measurements in a Japanese population using multidetector computed tomography. International Journal of Legal Medicine, 1-8. https://doi.org/10.1007/s00414-017-1728-x

Trivers, R. L. (1972). Parental investment and sexual selection. In B. M. Campbell (Ed.), Sexual Selection and the Descent of Man, 1871-1971 (pp. 136-179). Chicago: Aldine.

Trut, L., Kharlamova, A. V., Kukekova, A. V., Acland, G. M., Carrier, D. R., Chase, K., \& Lark, K. G. (2006). Morphology and Behavior: Are They Coupled at the Genome Level? In E. A. Ostrander, K. Lindblad-Toh, \& U. Giger (Eds.), The Dog and its Genome (Vol. 44, pp. 81-93). Cold Spring Harbor Laboratory Press. 
Masculinity and the mechanisms of human self-domestication-Ben Gleeson

1 Trut, L. N. (1999). Early Canid Domestication: The Farm-Fox Experiment. American Scientist, 87(2), 160. https://doi.org/10.1511/1999.2.160

Trut, L. N., Herbek, Y. E., Trapezov, O. V., Lashin, S. A., Matushkin, Y. G., Markel, A. L., \& Kolchanov, N. A. (2016). The Animal Domestication Experiment as a Model of the Evolutionary Process: A New Insight into Evolution Under Selection Targeting Regulatory Systems. In Genetics, Evolution and Radiation (pp. 455-477). Springer, Cham. https://doi.org/10.1007/978-3-319-48838-7_37

Trut, L. N., Kharlamova, A. V., Kukekova, A. V., Acland, G. M., Carrier, D. R., Chase, K., \& Lark, K. G. (2006). Morphology and Behavior: Are They Coupled at the Genome Level? In E. A. Ostrander, K. Lindblad-Toh, \& U. Giger (Eds.), The Dog and its Genome (Vol. 44, pp. 81-93). Cold Spring Harbor Laboratory Press.

Trut, L. N., Oskina, I., \& Kharlamova, A. (2009). Animal evolution during domestication: the domesticated fox as a model. BioEssays, 31(3), 349-360. https://doi.org/10.1002/bies.200800070

Trut, L., Oskina, I. N., \& Kharlamova, A. V. (2001). Experimental Studies of Early Canid Domestication. In E. A. Ostrander \& A. Ruvinsky (Eds.), Genetics of the Dog (2nd ed.). Oxfordshire, UK and Cambridge, MA, USA: CAB International.

Ueharu, H., Yoshida, S., Kikkawa, T., Kanno, N., Higuchi, M., Kato, T., ... Kato, Y. (2017). Gene tracing analysis reveals the contribution of neural crest-derived cells in pituitary development. Journal of Anatomy, 230(3), 373-380. https://doi.org/10.1111/joa.12572

Valasek, P., Theis, S., Krejci, E., Grim, M., Maina, F., Shwartz, Y., ... Patel, K. (2010). Somitic origin of the medial border of the mammalian scapula and its homology to the avian scapula blade. Journal of Anatomy, 216(4), 482-488. https://doi.org/10.1111/j.1469-7580.2009.01200.x 
Masculinity and the mechanisms of human self-domestication-Ben Gleeson

1 van Schaik, C. P. (2016). The Primate Origins of Human Nature (1 edition). Hoboken, New Jersey: Wiley-Blackwell.

3 Vandenbergh, J. G. (1965). Hormonal basis of sex skin in male rhesus monkeys. General and Comparative Endocrinology, 5(1), 31-34. https://doi.org/10.1016/00166480(65)90065-1

Verdonck, A., De Ridder, L., Verbeke, G., Bourguignon, J. P., Carels, C., Kühn, E. R., ... de Zegher, F. (1998). Comparative effects of neonatal and prepubertal castration on craniofacial growth in rats. Archives of Oral Biology, 43(11), 861-871. https://doi.org/10.1016/S0003-9969(98)00071-5

Verdonck, A., Gaethofs, M., Carels, C., \& de Zegher, F. (1999). Effect of low-dose testosterone treatment on craniofacial growth in boys with delayed puberty. European Journal of Orthodontics, 21(2), 137-143. https://doi.org/10.1093/ejo/21.2.137

White, F. J. (1996). Comparative socioecology of Pan paniscus. In W. C. McGrew, T.

White, F. J., Waller, M. T., \& Boose, K. J. (2013). Evolution of primate peace. In D. Fry Cultural Views (pp. 389-406). Oxford University Press.

White, F. J., \& Wood, K. D. (2007). Female feeding priority in bonobos, Pan paniscus, and the question of female dominance. American Journal of Primatology, 69(8), 837-850. https://doi.org/10.1002/ajp.20387

Whitehouse, A. J. O., Gilani, S. Z., Shafait, F., Mian, A., Tan, D. W., Maybery, M. T., ... Eastwood, P. (2015). Prenatal testosterone exposure is related to sexually dimorphic facial morphology in adulthood. Proceedings of the Royal Society B: Biological Sciences, 282(1816). https://doi.org/10.1098/rspb.2015.1351 
Masculinity and the mechanisms of human self-domestication-Ben Gleeson

1 Widmaier, E. P., Raff, H., Strang, K. T., \& Vander, A. J. (2010). Vander's Human York: McGraw Hill.

Wilkins, A. S., Wrangham, R. W., \& Tecumseh Fitch, W. (2014). The "domestication syndrome" in mammals: A unified explanation based on neural crest cell behavior and genetics. Genetics, 197(3), 795-808. https://doi.org/10.1534/genetics.114.165423

Windhager, S., Schaefer, K., \& Fink, B. (2011). Geometric morphometrics of male facial shape in relation to physical strength and perceived attractiveness, dominance, and masculinity. American Journal of Human Biology: The Official Journal of the Human Biology Council, 23(6), 805-814. https://doi.org/10.1002/ajhb.21219

Wobber, V., Hare, B., Lipson, S., Wrangham, R. W., \& Ellison, P. (2013). Different ontogenetic patterns of testosterone production reflect divergent male reproductive strategies in chimpanzees and bonobos. Physiology and Behavior, 116-117, 44-53. https://doi.org/10.1016/j.physbeh.2013.03.003

Wood, W., Kressel, L., Joshi, P. D., \& Louie, B. (2014). Meta-Analysis of Menstrual Cycle Effects on Women's Mate Preferences. Emotion Review, 6(3), 229-249. https://doi.org/10.1177/1754073914523073

Wrangham, R. W. (2014). Did Homo sapiens Self-Domesticate? Presented at the Center for Academic Research and Training in Anthropogeny: Domestication and Human Evolution. Retrieved from https://www.youtube.com/watch?v=acOZT240bTA

Wrangham, R. W. (2018). Two types of aggression in human evolution. Proceedings of the National Academy of Sciences, 115(2), 245-253.

https://doi.org/10.1073/pnas.1713611115 
Masculinity and the mechanisms of human self-domestication-Ben Gleeson

1 Wrangham, R. W., \& Glowacki, L. (2012). Intergroup Aggression in Chimpanzees and War in Nomadic Hunter-Gatherers. Human Nature, 23(1), 5-29. https://doi.org/10.1007/s12110-012-9132-1

Wright, D. (2015). The Genetic Architecture of Domestication in Animals. Bioinformatics and Biology Insights, 9(Suppl 4), 11-20. https://doi.org/10.4137/BBI.S28902

Zeder, M. A. (2008). Animal Domestication in the Zagros: an Update and Directions for Future Research. In E. Vila, L. Goucherin, A. Choyke, \& H. Buitenhuis (Eds.), Archaeozoology of the Near East VIII (Vol. 49, pp. 243-277). Lyon. Retrieved from http://www.persee.fr/doc/mom_1955-4982_2008_act_49_1_2709

Zeder, M. A. (2012). The Domestication of Animals. Journal of Anthropological Research, 68(2), 161-190.

Zeder, M. A. (2015). Core questions in domestication research. Proceedings of the National Academy of Sciences, 112(11), 3191-3198. https://doi.org/10.1073/pnas.1501711112

Zipser, B., Schleking, A., Kaiser, S., \& Sachser, N. (2014). Effects of domestication on biobehavioural profiles: a comparison of domestic guinea pigs and wild cavies from early to late adolescence. Frontiers in Zoology, 11, 30. https://doi.org/10.1186/17429994-11-30

Zollikofer, C. P. E., \& Ponce de León, M. S. (2010). The evolution of hominin ontogenies. Seminars in Cell \& Developmental Biology, 21(4), 441-452. https://doi.org/10.1016/j.semcdb.2009.10.012 